\title{
Production, Characterization and Immobilization of a Fusarium solani Lipase by Chitosan Magnetic Nanoparticles
}

\author{
A.M. EL-Sayed, Wedad E. Eweda*, T.S. EI-Tayeb*and A. \\ Z. Abdel Azeiz ${ }^{* * *}$ \\ Research \& Development Center, Misr University for Science \\ and Technology (MUST); "Agricultural Microbiology \\ Department, Faculty of Agriculture, Ain Shams University, and \\ ${ }^{* *}$ College of Biotechnology, Misr University for Science and \\ Technology (MUST), Cairo, Egypt.
}

\begin{abstract}
TIPASE producing fungus was isolated and identified as a strain of LFusarium solani based on its $18 \mathrm{~s}$ rDNA sequence. The enzyme it produces was purified by diethyl amino ethyl sephadex (DEAEsephadex) column chromatography. The specific activity of the pure enzyme was $1.98 \mathrm{U} / \mathrm{mg}$ protein. The kinetics study showed that $\mathrm{K}_{\mathrm{m}}$ and $\mathrm{V}_{\max }$ values were $0.63 \mu \mathrm{M}$ and $29.4 \mu \mathrm{M} / \mathrm{min} / \mathrm{mg}$ protein, respectively. The $\mathrm{MW}$ was $95.27 \mathrm{kDa}$. Effects of $\mathrm{pH}$, incubation temperature and organic solvents on the lipase activity were studied. The maximum enzyme activity was obtained at $\mathrm{pH} 8.5$ and incubation temperature $35^{\circ} \mathrm{C}$. Hexane and butanol inhibited enzyme activity by $51 \%$ and $72.6 \%$, respectively, while DMSO stimulated the activity by $47.8 \%$. The lipase was immobilized by fusion to chitosan-coated iron oxide magnetic nanoparticles and cross-linked by glutaraldehyde. The reusability and storage period of the immobilized enzyme showed that the enzyme retained $80 \%$ of its activity after 15 reuse cycles and retained $97 \%$ of activity after 30 days of storage at $4{ }^{\circ} \mathrm{C}$. The immobilized lipase was tested for synthesis of sugars-oleate esters and the ester products were analyzed by liquid chromatography tandemmass spectrometry (LC/MS/MS). This investigation identified the potential for use of the obtained $F$. solani lipase in industrial applications that utilize organic solvents or alkaline $\mathrm{pH}$ values, such as detergent industry.
\end{abstract}

Keywords: Fusarium solani, Lipases, Magnetic nanoparticles, Enzyme immobilization, Chitosan.

Lipases (EC 3.1.1.3) catalyze the hydrolysis of glycerides to free fatty acids, and glycerol. Due to their large number of applications, several studies have been conducted for isolation of lipase-producing microorganisms with various characters such as resistance to a wide range of temperatures, organic solvents, and to acidic and alkaline $\mathrm{pH}$. Lipases are used in pharmaceutical formulations such as cosmetics and to produce various intermediates used in manufacture of medicine (Rohit et al., 2001), as a biosensor and as a diagnostic tool (Pandey et al., 1999; Lott \& Lu, 1991 and Higaki et al., 2000). In the food industry lipases behave as a 
flavoring agent in dairy products, bakery, beverages, and meat and fish (Saxena, et al., 1999; Reetz, 2002 and Macedo et al., 2003). Lipases are used in detergents (Bajpai \& Tyagi, 2007 and Weerasooriya \& Kumarasinghe, 2012) and have environmental applications to hydrolyze oils and grasses (Pandey et al., 1999 and Lin et al., 2012) and for organic synthesis of esters that have a variety of applications (Berglund \& Hutt, 2000)

Immobilized enzymes increase enzyme stability at various $\mathrm{pH}$ values, temperatures and ionic strengths. Furthermore, immobilized enzymes can be recycled from the reaction mixture. Magnetic nanoparticles have several advantages as serving as the supporting material for immobilized enzymes over competing materials, providing a higher surface area that allows for greater enzyme loading, and by enabling separation from the reaction mixture by application of a magnetic field (Johnson et al., 2011).

This study aimed to isolate a lipase producing fungus and to characterize the enzyme by studying the effect of $\mathrm{pH}$, temperature, organic solvents, reusability and enzyme kinetics, as well as immobilization by chitosan-magnetite nanoparticles and application in sugar-ester synthesis.

\section{Materials and Methods}

Isolation of lipase producing fungi

Rhodamine-B agar medium was used for isolation of lipase producing fungi by a selective plating technique (Rajendiran et al., 2011).

Lipase assay

Lipase activity was determined using $p$-nitrophenyl palmitate ( $p$-NPP) (MW 377.52) (Sigma) as a substrate (Kantak et al., 2011)

\section{Fungus identification}

The fungal isolates were identified by using 18S-rDNA sequencing (Manoj et al., 2014). The $18 \mathrm{~S}$ rDNA sequence of a purified strain was amplified by PCR with forward primer 5'-CCTGGTTGATCCTGCCAG-3' and reverse primer 5'TTGATCCTTCTGCAGGTTCA- 3'. The PCR reactions were carried out as follows: one initial cycle at $95^{\circ} \mathrm{C}(5 \mathrm{~min})$, followed by 34 cycles of $95^{\circ} \mathrm{C}(1 \mathrm{~min})$, annealing at $55^{\circ} \mathrm{C}(1 \mathrm{~min}), 72{ }^{\circ} \mathrm{C}(1.5 \mathrm{~min})$ and ended with incubation at $72^{\circ} \mathrm{C}$ for $10 \mathrm{~min}$. The amplified product was electrophoresed on a $1.0 \%$ agarose gel. The fragment of interest was excised from the gel and purified with Rapid Recovery Kit (Gel), followed by sequencing (Sangon Shanghai, China). Sequence alignment of the 18S rRNA gene sequence with other sources in Genbank was performed by using the BLAST function at NCBI website (http://www.ncbi.nlm.nih.gov/) and then a phylogenetic tree was constructed with MEGA 3.1 software.

\section{Lipase production and purification}

A disk from a five days old slant of $F$. solani that had been grown on potato dextrose agar was used to inoculate $250 \mathrm{ml}$ conical flasks containing $50 \mathrm{ml}$ of the Egypt. J.Microbiol. 51 (2016) 
following production medium $(\mathrm{g} / \mathrm{l})$ : Olive oil: 10 , Peptone: $1, \mathrm{~K}_{2} \mathrm{HPO}_{4}$ : 1.0, $\mathrm{MgSO}_{4} \cdot 7 \mathrm{H}_{2} \mathrm{O}: 0.3, \mathrm{CaCl}_{2}: 0.25, \mathrm{ZnSO}_{4} \cdot 7 \mathrm{H}_{2} \mathrm{O}: 0.03, \mathrm{FeSO}_{4} \cdot 7 \mathrm{H}_{2} \mathrm{O}: 0.025, \mathrm{MnSO}_{4}$ - $7 \mathrm{H}_{2} \mathrm{O}: 0.015$. The flasks were incubated for five days on a rotary shaker at $28 \pm 2{ }^{\circ} \mathrm{C}$ and $150 \mathrm{rpm}$. The enzyme was precipitated from the supernatant by stepwise addition of $150 \mathrm{ml}$ of cooled acetone to $100 \mathrm{ml}$ of the supernatant under continuous stirring. The enzyme precipitate was separated by centrifugation at $8000 \mathrm{rpm}$ for $15 \mathrm{~min}$ under cooling. The precipitate was dissolved $0.02 \mathrm{M}$ sodium phosphate buffer ( $\mathrm{pH}$ 6.6). The enzyme was purified using DEAE-sephadex (Sigma) column stepwise eluted by $5 \mathrm{ml}$ portions of a mixture of phosphate buffer (pH 6.6): $\mathrm{NaCl}$ (100: 0), (95:5), up to (0: 100\%). Thirty eight fractions were collected. Soluble protein was determined by Lowry method (Lowry et al., 1951) and the specific activity was calculated as U/mg protein.

\section{MW determination}

The molecular weight of purified lipase enzyme was determined by SDSPAGE. The gel image was analyzed by gel documentation software (Alpha Ease FC 4.0).

\section{Enzymes kinetics study}

The Michaelis-constant and maximum velocity $\left(\mathrm{K}_{\mathrm{m}}\right.$ and $\left.\mathrm{V}_{\max }\right)$ of the purified lipases were determined by using various concentrations of $p$-nitrophenyl palmitate as substrate from $0.2 \mathrm{mg} / 100 \mu \mathrm{L}$ to $1.2 \mathrm{mg} / 100 \mu \mathrm{L}$. The values of kinetic parameters, $\mathrm{K}_{\mathrm{m}}$ and $\mathrm{V}_{\max }$ were determined from a Lineweaver-Burk plot.

Effect of $p H$ and temperature on the lipase stability

Buffer solutions $(50 \mathrm{mM})$ of different $\mathrm{pH}$ values were used which includes citrate buffer (4-5), phosphate buffer (6-7) and Tris- $\mathrm{HCl}$ buffer (8-9). The purified enzyme was incubated for $30 \mathrm{~min}$ in buffers with varying $\mathrm{pH}$ values at $35^{\circ} \mathrm{C}$ and then the enzyme activity was determined. To study the effect of temperature, the purified enzyme solution in phosphate buffer $(50 \mathrm{mM}) \mathrm{pH} 6.6$, was incubated for $30 \mathrm{~min}$ at $5,15,25,35,45,55$ and $65{ }^{\circ} \mathrm{C}$ followed by determination of the enzyme activity.

\section{Effect of organic solvents}

Equal volumes of substrate solution and one of the tested organic solvents (DMSO, acetone, acetonitrile, ethanol, iso-propanol, ethyl acetate, methanol, butanol or hexane) were mixed and left for $30 \mathrm{~min}$ at $35^{\circ} \mathrm{C}$ before assaying for enzyme activity.

\section{Preparation of magnetic nanoparticles based on iron oxide}

The iron oxide magnetic nanoparticles $\left(\mathrm{Fe}_{3} \mathrm{O}_{4}\right.$-MNPs) were prepared by coprecipitation of ferric chloride $\left(\mathrm{FeCl}_{3} \cdot 6 \mathrm{H}_{2} \mathrm{O}, 99 \%\right)$, ferrous chloride $\left(\mathrm{FeCl}_{2} \cdot 4 \mathrm{H}_{2} \mathrm{O}\right.$, $98 \%)$ and aqueous ammonia $\left(\mathrm{NH}_{4} \mathrm{OH}, 57.6\right.$ wt. \%). 0.02M of ferric chloride and $0.01 \mathrm{M}$ of ferrous chloride were dissolved in $250 \mathrm{~mL}$ distilled water. The solution was heated at $60{ }^{\circ} \mathrm{C}$ with stirring and $50 \mathrm{ml}$ of $0.01 \mathrm{M} \mathrm{NH} \mathrm{NH}_{4} \mathrm{OH}$ was drop-wise added during heating. The solution was allowed to stand for $2 \mathrm{~h}$. The separated 
iron oxide magnetic nanoparticles were recovered by using a permanent magnet, washed two times with distilled water and lyophilized to obtain the final product (Kuo et al., 2012).

Characterization of iron oxide magnetic nanoparticles

$\mathrm{X}$-ray diffraction was performed to ensure the chemical composition of $\mathrm{Fe}_{3} \mathrm{O}_{4}$-MNPs, while the particle size were determined by JEOL JEM-2000 EX model scanning- electron microscope (SEM).

Preparation of chitosan-coated iron oxide magnetic nanoparticles

Chitosan was prepared from shrimp exoskeleton by the method described by Huang et al. (2004). Half g chitosan in $100 \mathrm{ml}$ of $2 \% \mathrm{v} / \mathrm{v}$ acetic acid solution was mixed with $25 \mathrm{ml}$ of $1 \mathrm{mg} / \mathrm{ml}$ sodium tripolyphosphate solution as a cross-linker to enhance colloidal stability, left for 10 min., followed by addition of $0.1 \mathrm{~g}$ of iron oxide magnetic nanoparticles $\left(\mathrm{Fe}_{3} \mathrm{O}_{4}\right.$-MNPs) and vigorously stirred for 30 min. Fifty milliliter of $1 \mathrm{~N} \mathrm{NaOH}$ was added slowly to the suspension to precipitate the chitosan coated iron oxide magnetic nanoparticles. The particles were recovered from the suspension by using a permanent magnet and washed with distilled water several times until the $\mathrm{pH}$ reached 7.0 , then $10 \mathrm{ml}$ of different concentrations ranging from $1 \%$ to $4 \%$ glutaraldehyde were added to the mixture and stirred for $2 \mathrm{~h}$. The cross-linked nanoparticles were filtered and washed by phosphate buffer $(0.05 \mathrm{M}, \mathrm{pH} 7.0)$ solution five times and stored in the refrigerator $\left(4^{\circ} \mathrm{C}\right)$ till later use (Kuo et al., 2012).

Immobilization of lipases by chitosan-coated iron oxide magnetic nanoparticles

Ten $\mathrm{ml}$ of the chitosan-iron oxide nanoparticles $(2 \mathrm{mg} / \mathrm{ml})$ were mixed with an equal volume of lipase in Tris- $\mathrm{HCl}$ buffer $(0.05 \mathrm{M}, \mathrm{pH}$ 8.5) solution. The mixture was shaken at room temperature for $6 \mathrm{~h}$. The immobilized lipases on chitosancoated iron oxide magnetic nanoparticles were recovered by using a permanent magnet and washed five times by phosphate buffer solution ( $0.05 \mathrm{M}, \mathrm{pH} 7.0)$. The yield and efficiency of immobilized lipase was determined (Kuo et al., 2012).

\section{Reusability and storage stability of immobilized lipase}

The activity of immobilized lipase was measured after up to twenty cycles of reuse. In order to investigate storage stability, the activity of both free and immobilized lipases were determined weekly during storage for 30 days at $4{ }^{\circ} \mathrm{C}$.

Statistical analysis

The collected data were analyzed using ANOVA statistical analysis, by Design-Expert software version 7.0.0 (Camila et al., 2011).

\section{Results and Discussion}

Identification of the most efficient fungal isolate

The most active fungal isolate was identified by cultural and morphological characteristics, and 18s rDNA sequence. According to BLAST result and 
phylogenetic tree, the fungal isolate showed the most identity with Fusarium solani strain ZK004 with identity percent $98 \%$. The topology of the resulting dendrogram (Fig. 1) showed that Fusarium solani strain ZK004 has high similar to the same cluster of Fusarium falciform \& Fusarium oxysporum. The Blast searching showed that the strain of Fusarium solani ZK004 has more differences not only to the strain of Fusarium incarnatum from the database, but also with strain of Gibberella moniliformis, which is the name for the perfect stage of Fusarium verticillioides. Several previous investigations have been conducted for lipase production form Fusarium sp. (Maria et al., 1999; Rafael et al., 2014 and Fernanda et al., 2015).

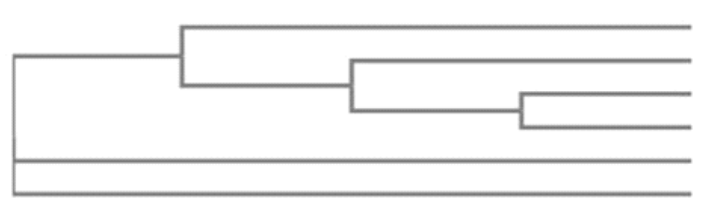

\author{
Fusarium_oxysporum \\ Fusarium_falciform \\ Sample \\ Fusarium_solani ZKOO4* \\ Gibberella_moniliformis \\ Fusarium_incarnatum
}

Fig. 1. Dendrogram after Clustal W2 multiple alignment of the 18srDNA sequences. (*) The tested strain obtained from NCBI Genbank by Blast searching •

\title{
Lipase purification
}

The lipase activity in the fugal supernatant was $23.2 \mathrm{U} / \mathrm{ml}$. The enzyme activity after precipitation by acetone and DEAE-Sephadex purification were 21.1 and $17.1 \mathrm{U} / \mathrm{ml}$, respectively. These results reflect some loss in the enzyme during purification. However, the specific activity was increased after the Sephadex purification from 0.88 to $1.98 \mathrm{U} / \mathrm{mg}$ protein. As shown in Fig. 2, the lipase is eluted in fraction number 27.

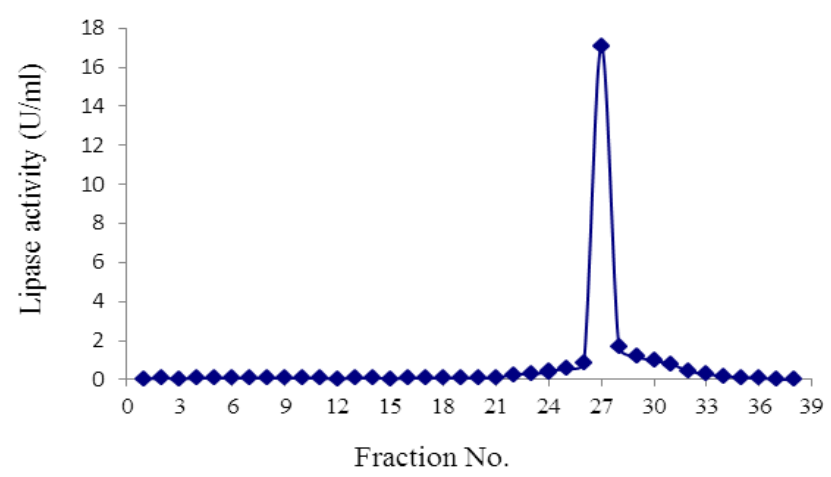

Fig. 2. Lipase activity in the fractions collected from DEAE-Sephadex column. 
Lipase kinetics study

Lineweaver-Burk plot (Fig. 3) showed that $K_{m}$ and $V_{\max }$ values were $0.63 \mu \mathrm{M}$ and 29.4uM, respectively.

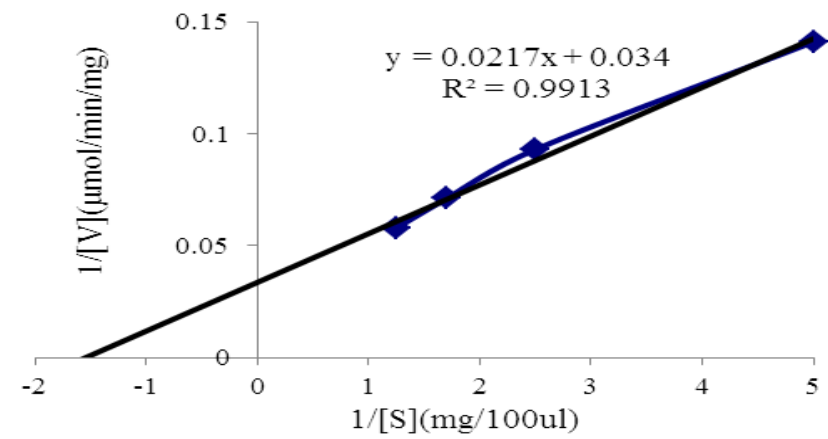

Fig. 3. Lineweaver-Burk plot for calculation of $K_{m}$ and $V_{\max }$ values of $F$. solani lipase.

Molecular weight determination of lipase

The approximate molecular weight of the purified lipase enzyme is 95.27 kDa (Fig. 4).

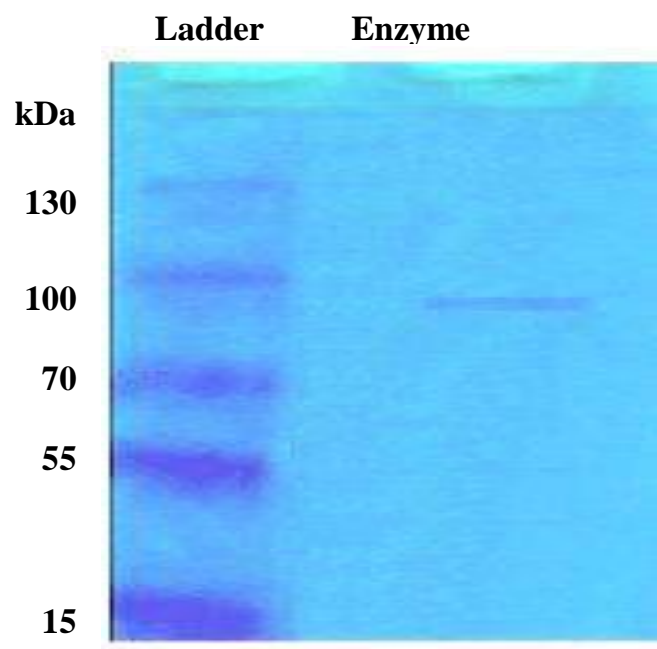

Fig. 4. SDS-PAGE showing the molecular weight of the purified lipase as compared with the protein ladder.

Effect of $\mathrm{pH}$ and temperature on the lipase stability

As shown in Fig. 5a, the maximum lipases activity was observed at $\mathrm{pH}$ 8.5. Therefore, we recommend use of this enzyme in detergents and alkaline applications. This result was in agreement with Kasana et al. (2008) and Amoozegar et al. (2008), where the enzyme was stable at $\mathrm{pH}$ range of 7.5-8.0 and retained $90 \%$ of its activity. On the other hand, maximum lipase activity was Egypt. J.Microbiol. 51 (2016) 
obtained at $35^{\circ} \mathrm{C}$ (Fig. 5b). Further increase in the incubation temperature inhibited the enzyme. Other alkaline lipases were previously isolated from Fusarium globulosum and Rhizopus delemar (Gulati et al., 2005 and Haas et al., 2011).

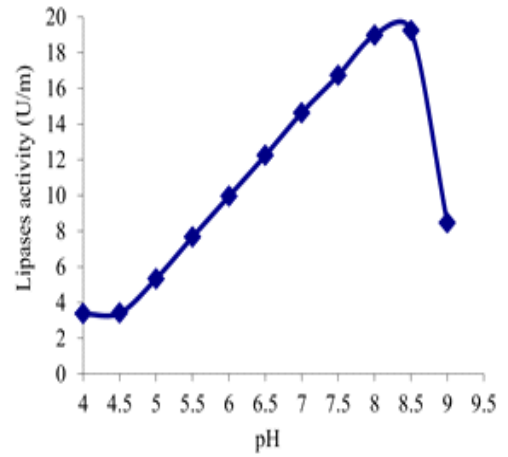

(a)

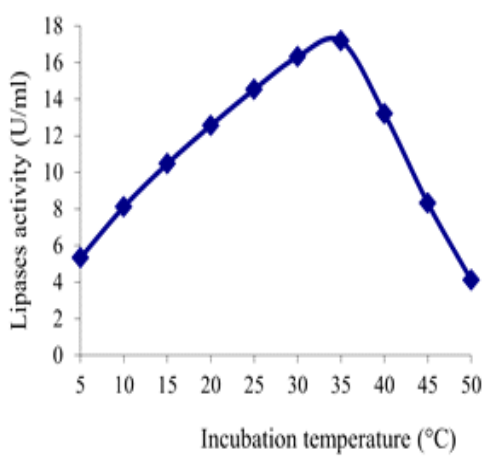

(b)

Fig. 5. Effect of $\mathrm{pH}$ and temperature on $F$. solani lipase stability.

Effect of organic solvents on the F. solani lipase activity

Stability against organic solvents is very important when using an enzyme in industrial applications such as synthesis of esters. The lipase activity was increased by $47.8 \%$ in presence of DMSO (dimethyl sulfoxide). Also, acetone, acetonitrile, iso-propanol, ethanol, methanol and ethyl acetate increases the enzyme activity (Fig. 6). This effect may be due to the solvent molecules interaction with hydrophobic amino acid residues present in the 'lid' that covers the catalytic site of the enzyme, thereby maintaining the lipase in a suitable conformation for the catalytic reaction. On the other hand, hexane and butanol inhibited the enzyme activity. These results were useful when using the obtained lipase for organic-synthesis reactions or other applications that include use of organic solvents (Doukyu \& Ogino, 2010).

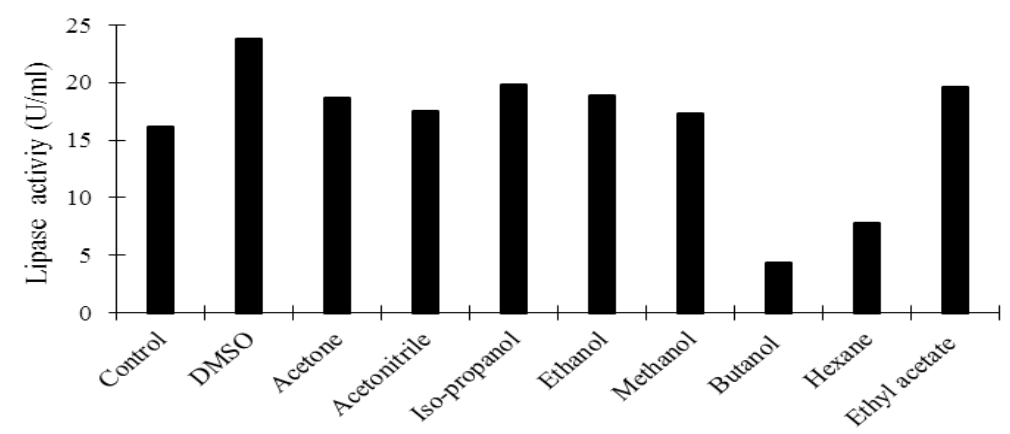

Fig. 6. Effect of organic solvents on the $F$. solani lipase activity. 
Characterization of iron oxide magnetic nanoparticles $\left(\mathrm{Fe}_{3} \mathrm{O}_{4}-\mathrm{MNPs}\right)$

$\mathrm{X}$-ray diffraction verified the chemical composition of $\mathrm{Fe}_{3} \mathrm{O}_{4}$-MNPs. Scanning- electron microscopy described the size and shape of the iron oxide magnetic nanoparticles as rods with average length of $100 \mathrm{~nm}$. (Fig. 7).

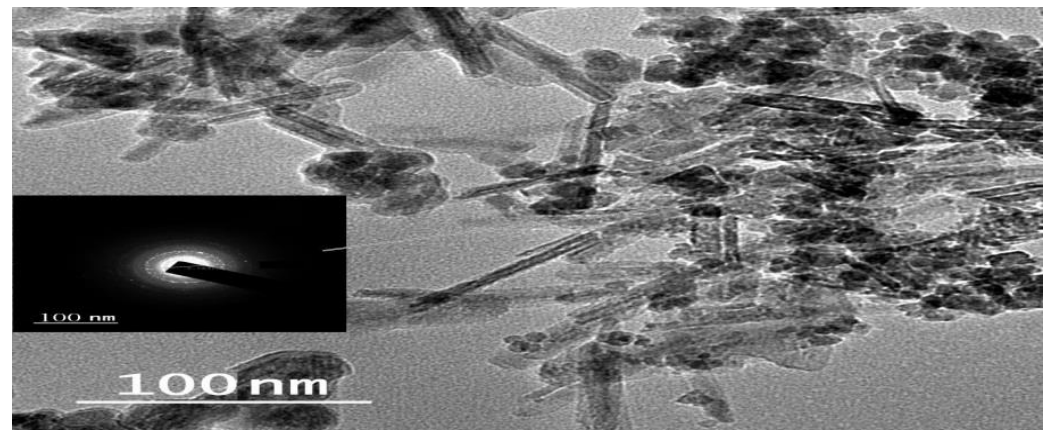

Fig. 7. SEM image for the iron oxide magnetic nanoparticles.

\section{Reusability of the immobilized lipase}

The reusability of the immobilized enzyme is one of the most important parameter that reflects how long this enzyme can be used, which is particularly interesting in terms of the economics of large-scale processes. The activity of the lipases immobilized onto chitosan-coated magnetic nanoparticles was measured after up to twenty cycles of reuse. After fifteen cycles of reuse, the lipases activity was retained up to $80 \%$ of the initial activity (Fig. 8).

The immobilization of Mucor javanicus lipases onto chrysotile (magnesium silicate) decreased the yield by $25 \%$ after its first reuse and by more than $70 \%$ after four reuse cycles (Silva \& Jesus, 2003). On contrary, the covalent immobilization of Rhizopus oryzae lipases onto silica gel decreased the residual activity by only $20 \%$ after twenty reuse cycles (Lee et al., 2006). The results obtained here were in agreement with Wang et al. (2010) who observed a slight decrease of enzyme activity $(<15 \%)$ after 12 cycles of reuse.

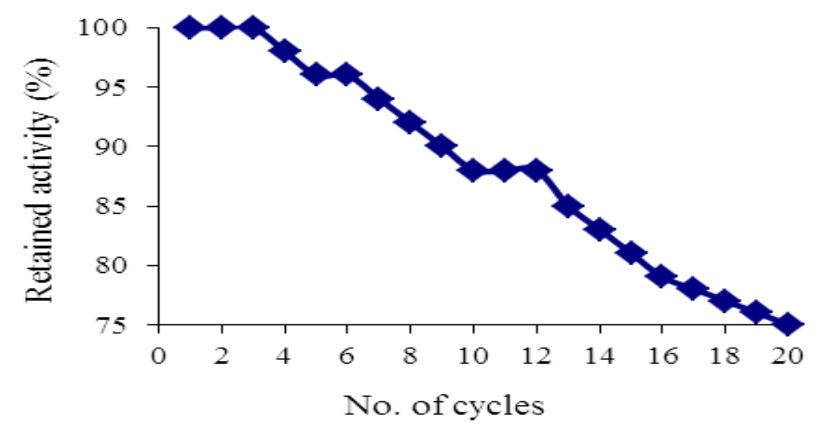

Fig. 8. Reusability of lipase immobilized onto chitosan-coated magnetic nanoparticles cross-linked by glutaraldehyde.

Egypt. J.Microbiol. 51 (2016) 
Storage stability of the immobilized lipases

The activity of free lipase decreased to $87 \%$ after four weeks; while the immobilized lipases decreased to only $97 \%$ after four weeks of storage at $4{ }^{\circ} \mathrm{C}$. This result reflects the effect of the immobilization process in preserving enzyme activity.

Application of immobilized lipases for sugar ester synthesis

The use of lipase in organic synthesis (green synthesis) of esters is one of the most important applications. It was tested to synthesis sugar-esters of oleic acid. LC/MS/MS analysis of the ester products showed presence of mono and di-oleate glucose esters with molecular weight of 443.62 and 708.08 , respectively. The molecular weights of mono oleate fructose and mannitol were 443.62 and 445.64, respectively (Fig. 9). Lipases have been used by many researchers for synthesis of sugar esters. Ferrer et al. (2005) utilized lipase from Thermomyces lanuginosus and Candida antarctica for synthesis of vinyl-sugars esters due to their antimicrobial activities. Lee et al. (2007) utilized lipase for synthesis of glucose-lauryl ester, while lipase of Candida antarctica was utilized by Jintian et al. (2012).
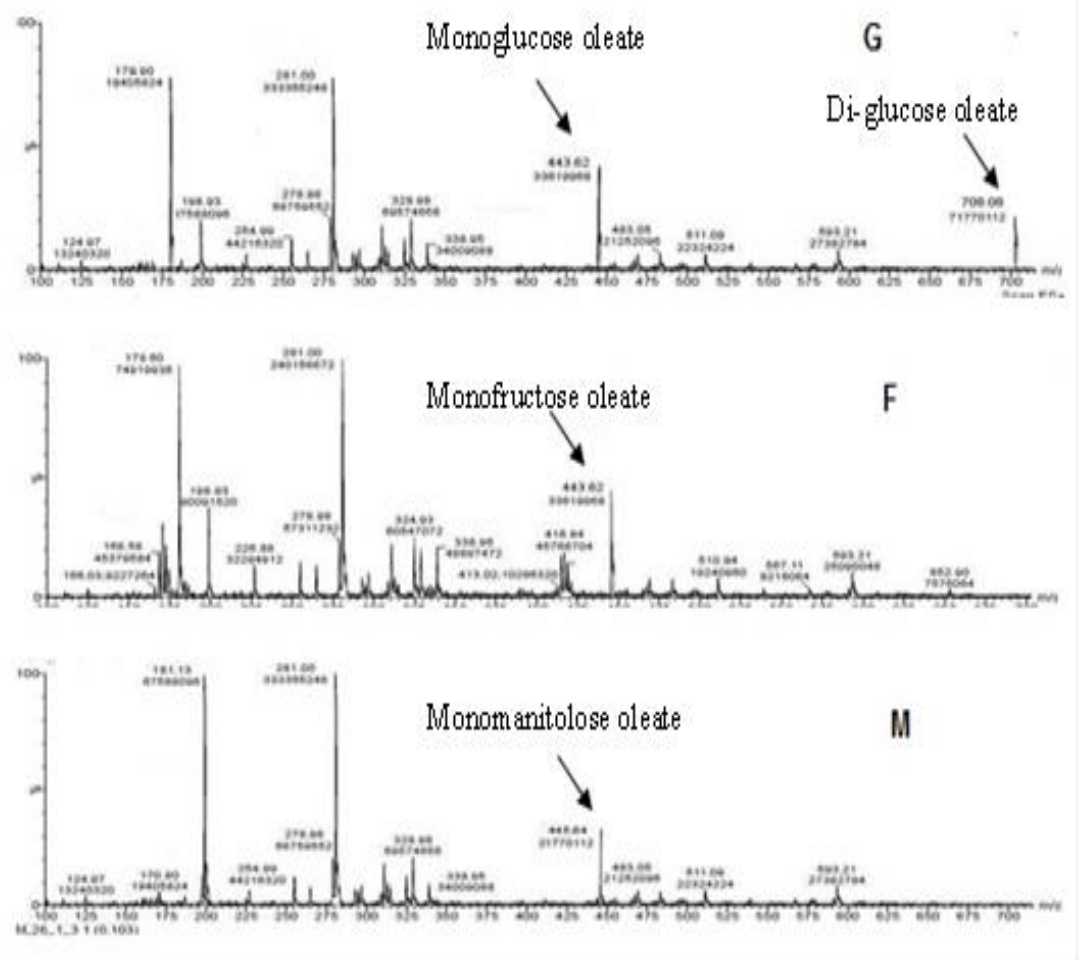

Fig. 9. LC/MS/MS spectra of the ester products synthesized by lipase with glucose (G), fructose (F) and mannitol (M). 


\section{References}

Amoozegar, M.A., Salehghamari, E., Khajeh, K., Kabiri, M. and Naddaf, S. (2008 ) Production of an extracellular thermohalophilic lipase from a moderately halophilic bacterium, Salinivibrio sp. strain SA-2. J. Basic Microbiol. 48 (3), 160-7.

Bajpai, D. and Tyagi, V.K. (2007) Laundry detergents: An overview, J. Oleo. Sci. 56, 327-340.

Berglund, P. and Hutt, K., (2000) Biocatalytic synthesis of enantio-pure compounds using lipases. In: "Stereoselective Biocatalysis". Patel, R.N., Ed.. New York: Marcel Dekker.

Camila, A.P., Pacheco, C. and Carin, M.E. (2011) Preparation and modification of chitosan particles for Rhizomucor miehei lipase immobilization. Biochemical Engineering Journal, 55, 199- 207.

Doukyu, N. and Ogino, H. (2010) Organic solvent-tolerant enzymes. Biochem. Eng. J. 48, 270-282.

Fernanda, A.F., Ana, C.V., Marita, G.P., João, A.J. and Maria, T.M. (2015) Enhanced lipase production of Fusarium verticillioides by using response surface methodology and wastewater pretreatment application. J. Biochem. Tech. 6 (3), 9961002.

Ferrer, M., Soliveri, J., Plou, F.J., López-Cortés, N., Reyes-Duarte, D., Christensen, M., Copa-Patiño, J.L. and Ballesteros, A. (2005) Synthesis of sugar esters in solvent mixtures by lipases from Thermomyces lanuginosus and Candida antarctica B, and their antimicrobial properties. Enzyme and Microbial Technology, 36, 391-398.

Gulati, R., Isar, J., Kumar, V., Prasad, A.K., Parmar, V.S. and Saxena, R.K. (2005) Production of a novel alkaline lipase by Fusarium globulosum using neem oil, and its applications. Pure Appl. Chem. 77 (1), 251-262.

Haas, M.J., Cichowicz, D.J. and Bailey, D.G. (2011) Purification and characterization of an extracellular lipase from the fungus Rhizopus delemar. Lipids, 27 (8), 571-576.

Higaki, S., Kitagawa, T., Kagoura, M., Morohashi, M. and Yamagishi, T. (2000) Correlation between Propionibacterium acnes biotypes, lipase activity and rash degree in acne patients. J. Dermatol. 27, 519-522.

Huang, M. et al. (2004) Uptake and cytotoxicity of chitosan molecules and nanoparticles: Effects of molecular weight and degree of deacetylation. Pharmaceutical Research, 21 (2), 344-353.

Jintian Liang, Wentian Zeng, Pingjia Yao and Yuanan Wei (2012) Lipase-catalyzed regioselective synthesis of palmitolyglucose ester in ionic liquids. Advances in Biological Chemistry, 2, 226-232

Johnson, P.A., Park, H.J. and Driscoll, A.J. (2011) Enzyme nanoparticle fabrication: Magnetic nanoparticle synthesis and enzyme immobilization. Methods Mol. Biol., 679, 183-91. doi: 10.1007/978-1-60761-895-9_15.

Egypt. J.Microbiol. 51 (2016) 
Kantak, J.B., Bagade, A.V., Mahajan, S.A., Pawar, S.P., Shouche, Y.S. and Prabhune, A.A. (2011) Isolation, identification and optimization of a new extracellular lipase producing strain of Rhizopus sp. Appl. Biochem. Biotechnol. 164, 969-978.

Kasana, R.C., Kaur, B. and Yadav, S.K. (2008) Isolation and identification of a psychrotrophic Acinetobacter sp. CR9 and characterization of its alkaline lipase. J. Basic Microbiol. 48 (3), 207-12.

Kuo, C., Liu, Y., Chang, C., Chen, J., Chang, C. and Shieh, C. (2012) Optimum conditions for lipase immobilization on chitosan-coated $\mathrm{Fe}_{3} \mathrm{O}_{4}$ Nanoparticles. Carbohydrate Polymers, 87, 2538-2545.

Lee, D.H., Park, C.H., Yeo, J.M. and Kim, S.W. (2006) Lipase immobilization on silica gel using a cross-linking method. J. Ind. Eng. Chem. 12, 777-782.

Lee, S.H. Ha, S.H., Dang, D. T., Chang, Woo-Jin and Koo, Yoon-Mo (2007) Lipasecatalyzed synthesis of fatty acid sugar ester using extremely supersaturated sugar solution in ionic liquids. Biotechnology and Bioengineering, 99 (1), 1-8.

Lin, J.F., Lin, Q., Li, J., Fei, Z.A., Li, X.R., Xu, H., Qiao, D.R. and Cao, Y., (2012) Bacterial diversity of lipase-producing strains in different soils in southwest of China and characteristics of lipase, Afr. J. Microbiol. Res. 6 (16), 3797-3806.

Lott, J.A. and Lu, C.J. (1991) Lipase isoforms and amylase isoenzymes - assays and application in the diagnosis of acute pancreatitis, Clin. Chem. 37, 361-368

Lowry, O.H., Rosebrough, N.J., Farr, A.L. and Randall, R.J. (1951) Protein measurement with the Folin phenol reagent.. J. Biol. Chem. 193 (1), 265-675.

Lu, A.H., Salabas, E.L. and Angew, F.S. (2007) Magnetic nanoparticles: synthesis, protection, functionalization, and application. Chem. Int. Ed. 46, 1222 - 1244.

Macedo, G.A., Lozano, M.M.S. and Pastore, G.M. (2003) Enzymatic synthesis of short chain citronellyl esters by a new lipase from Rhizopus sp., Electron. J. Biotechnol. 6 (1), $72-75$.

Manoj, K.S., Singh, J., Kumar, M. and Thakur, I.S. (2014) Novel lipase from basidiomycetes Schizophyllum commune ISTL04,produced by solid state fermentation of Leucaena leucocephala seeds. Journal of Molecular Catalysis B: Enzymatic, 110, 92-99.

Maria, M.D., Marcia, M.C., Marcos, A.M., Eduardo, H.M. and José, L.F. (1999) Production of extracellular lipase by the phytopathogenic fungus Fusarium solani FS1. Rev. Microbiol. 30 (4), 304-309.

Pandey, A., Benjamin, S., Soccol, C.R., Nigam, P., Krieger, N. and Soccol, V.T. (1999) The realm of microbial lipases in biotechnology, Appl. Biochem. Biotechnol. 29 (2), 119131.

Rafael, R.M., Gabriela, A.M. and Maria, I.R. (2014) Lipase production using microorganisms from different agro-industrial by-products. International Journal of Applied Science and Technology, 4 (1), 108-115. 
Rajendiran, R., Gayathri devi, S., SureshKumar, B.T. and Arul Priya, V. (2011) Screening of process variables for the production of extracellular lipase from palm oil by Trichoderma viride using plackett- burman design. World Academy of Science, Engineering and Technology, 75, 7743-7746.

Reetz, M.T. (2002) Lipases as practical biocatalysts, Curr. Opin. Chem. Biol. 6 (2), 145-150 .

Rohit Sharma, Yusuf Chisti and Uttam, C.B. (2001) Production, purification, characterization and applications of lipases. Biotechnology Advances, 19, 627-662.

Saxena, R.K., Ghosh, P.K., Gupta, R., Davidson, W.S., Bradoo, S. and Gulati, R. (1999) Microbial lipases: Potential biocatalysts for the future industry, Curr. Sci. 77 (1), 101-115.

Silva, J.E.S. and Jesus, P.C. (2003) Evaluation of the catalytic activity of lipases immobilized on chrysotile for esterification. Ann. Acad. Braz. Sci. 75, 157-162.

Wang, S.G., Zhang, W.D., Li, Z., Ren, Z.Q. and Liu, H.X. (2010) Lipase immobilized on the hydrophobic polytetrafluoroethene membrane with nonwoven fabric and its application in intensifying synthesis of butyl oleate. Appl. Biochem. Biotech. 162, 2015-2026.

Weerasooriya, M.K.B. and Kumarasinghe, A.A.N. (2012) Isolation of alkaline lipase from rubber seed- Partial purification, characterization and its potential applications as a detergent additive. Indian J. Chem. Techn. 19, 244-249. 
PRODUCTION, CHARACTERIZATION AND IMMOBILIZATION ...

إنتاج و توصيف إنزيم الليبيز المنتج من Fusarium solani و تثبيته بواسطة حبيبات الكيتوزان المغلفة بأكسيد الحديد المنتف المغناطيسي بحجم النانو

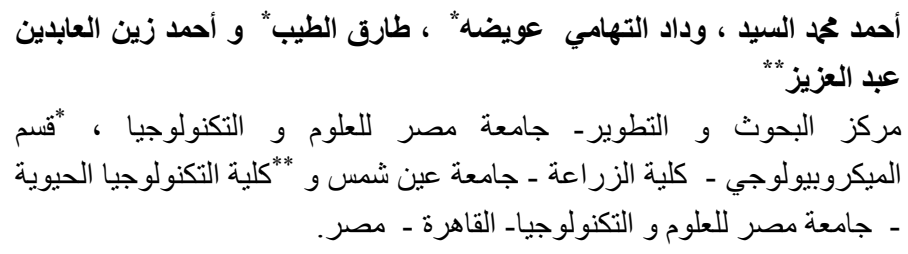

18s- تم عزل أحد الفطريات المنتجة لإنزيم الليبيز و تعريفه عن طريق تتابع جين

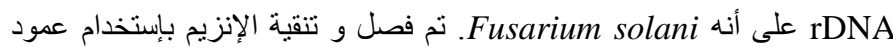

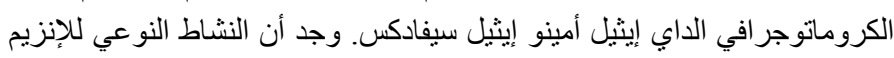

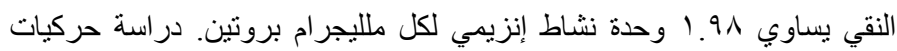

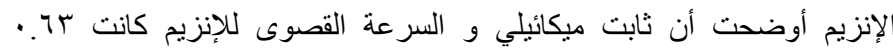

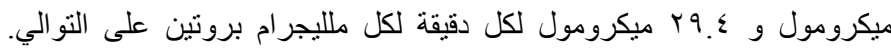

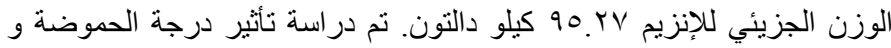

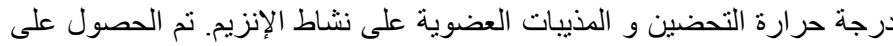

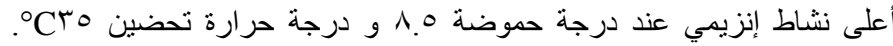

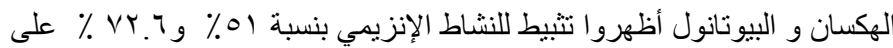

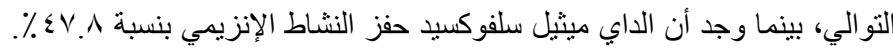

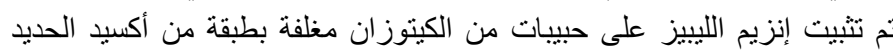

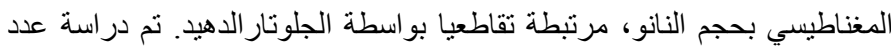

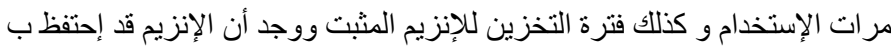

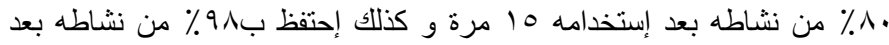

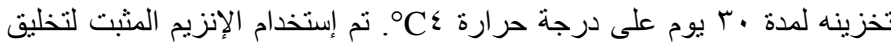

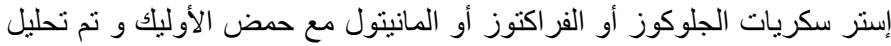

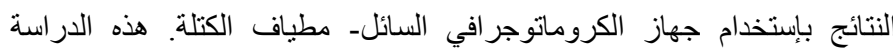

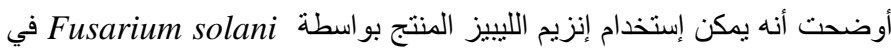

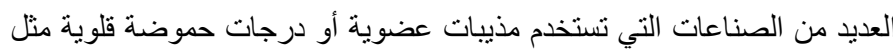

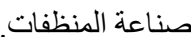

